\title{
Short communication: Forward and inverse models relating river long profile to monotonic step-changes in tectonic rock uplift rate history: A theoretical perspective under a nonlinear slope-erosion dependency
}

5 Yizhou Wang ${ }^{1}$, Liran Goren ${ }^{2}$, Dewen Zheng ${ }^{3}$, Huiping Zhang ${ }^{1}$

${ }^{1}$ State Key Laboratory of Earthquake Dynamics, Institute of Geology, China Earthquake Administration, Beijing 100029, China

${ }^{2}$ Department of Earth and Environmental Sciences, Ben-Gurion University of the Negev, Beer-Sheva, Israel ${ }^{3}$ Guangzhou Institute of Geochemistry, Chinese Academy of Sciences, Guangzhou 510640, China

Correspondence to: Yizhou Wang (wangyizhou2016@outlook.com)

\begin{abstract}
The long profile of rivers is widely considered as a recorded of tectonic uplift rate. Knickpoints form in response to rate changes and faster rates produce steeper channel segments. However, when the exponent relating fluvial incision to river slope, $n$, is not unity, the links between tectonic rates and channel profile are complicated by channel dynamics that consume and form river segments. Here, we explore non-linear cases leading to channel segment consumption and develop a

15 Lagrangian analytic model for knickpoint migration. We derive a criterion for knickpoint preservation and merging, and develop a forward analytic model that resolves knickpoint and long profile evolution before and after knickpoint merging. We further propose a linear inverse scheme to infer tectonic history from river profiles when all knickpoints are preserved. Our description provides a new framework to explore the links between tectonic uplift rates and river profile evolution when $n$ is not unity.
\end{abstract}

\section{Introduction}

Bedrock rivers that incise into tectonically active highlands are sensitive to changes in the tectonic conditions (Whipple and Tucker, 1999; Kirby et al., 2003). Upon a change in the rock uplift rate with respect to a base level, the river steepness changes (Wobus et al., 2006; Kirby and Whipple, 2001; Whipple and Tucker, 2002), which in turn, changes the local incision rate. Particularly, an increase in uplift rate generates steeper slopes that facilitate faster incision, overall promoting incision-uplift equilibrium. However, equilibration is not achieved synchronously across the river long profile. Upon a tectonic change, a knickpoint forms that divides the profile to reaches with different steepness and erosion rates (Rosenbloom and Anderson, 1994; Berlin and Anderson, 2007; Oskin and Burbank, 2007). Below the knickpoint, the steepness and erosion rate have already been shaped by the new tectonic conditions, while above the knickpoint, river steepness and erosion rate correspond to the previous conditions (Niemann et al., 2001; Kirby and Whipple, 2012). The 
30 erosion rate gradient across the knickpoint promotes knickpoint migration upstream, gradually changing the proportion of the channel that is equilibrated to the new tectonic conditions. Therefore, knickpoints are viewed as moving boundaries that separate channel reaches recording different portions of the tectonic history (e.g., Pritchard et al., 2009; Whittaker and Boulton, 2012).

Since the links between tectonic history and river shape are mediates by fluvial incision, resolving these links requires a

35 fluvial incision theory. The Stream-Power Incision Model (SPIM) is a leading theory that is widely used to describe detachment-limited vertical incision into channel bedrock, over long-timescales (commonly beyond millennials) and large length scales (Howard and Kerby, 1989; Snyder et al., 2000; Lague, 2014; Venditti et al., 2019). The SPIM represents the rate of bedrock incision, $E(\mathrm{~L} / \mathrm{T})$ as a power-law function of channel slope $(S=\partial z / \partial x, \mathrm{~L} / \mathrm{L})$ and upstream drainage $\operatorname{area}\left(A, \mathrm{~L}^{2}\right)$, which is used as a proxy for both discharge and channel width (Howard and Kerby, 1989):

$40 E(x, t)=K A(x)^{m}\left[\frac{\partial z(t, x)}{\partial x}\right]^{n}$,

where $x(\mathrm{~L})$ denotes a spatial coordinate along the channel and $t(\mathrm{~T})$ is time. The channel erodibility, $K\left(\mathrm{~L}^{1-2 m} / \mathrm{T}\right)$, primarily depends on the bedrock lithology, and the effective rate of precipitation (Whipple and Tucker, 1999; Snyder et al., 2000). The positive exponents, $m$ and $n$, control the sensitivity of incision rate to the drainage area and slope, respectively. Assigning equation (1) in a topography conservation equation gives rise to a partial differential equation describing the time-

45 space evolution of the fluvial channel long profile:

$\frac{\partial z(t, x)}{\partial t}=U(t, x)-K A^{m}\left[\frac{\partial z(t, x)}{\partial x}\right]^{n}$,

where $U(\mathrm{~L} / \mathrm{T})$ is the rate of tectonic uplift. Notably, the formulation of equation (2) represents many simplifications of the processes of river bedrock incision. For example, it does not explicitly account for incision thresholds, discharge variability, sediment flux incision sensitivity, and dynamic changes in channel width (Lave and Avouac, 2001; Whipple and Tucker,

50 2002; Duvall et al., 2004; Lague et al., 2005; Dibiase et al., 2010). However, Gasparini and Brandon (2011) argued that many of these processes could still be approximated by modifying the exponents, $m$ and $n$.

Equation (2) is a non-linear advection equation for the elevation, where $U$ acts as a forcing term. Consequently, equation (2) predicts the first-order dynamics of bedrock rivers, whereby knickpoints form in response to tectonic changes and migrate upstream. The relative simplicity of equation (2) presents a unique opportunity for an analytic exploring of channel dynamics

55 in response to changing tectonic and environmental conditions. Particularly, when the analytic solution is sufficiently simple, its representation can be used as part of forward models that predict topographic evolution (e.g., Steer, 2021), and inverse models that infers the tectonic history from observations river long profiles (Fox et al., 2015; Rudge et al., 2015; Gallen and Fernández-Blanco, 2021; Goren et al., 2021). 
Previous, general analytic exploration of equation (2) (e.g., Luke, 1972; Weissel and Seidl, 1998; Prichard et al., 2009;

60 Royden and Perron, 2013) have identified that upon a tectonic change that induces a long-profile steepness change, portions of the solution, representing the river profile, could form that are not strictly associated with the tectonic change, and, portions of the solution that hold tectonic information may be lost. More specifically, when $U$ increases and $n<1$ or $U$ decreases and $n>1$, 'stretched zone' along a river long profile form that are not associated with any particular tectonic input (Royden and Perron, 2013). When $U$ increases and $n>1$ or $U$ decreases and $n<1$, some portions of the channel reach are consumed at knickpoints (Royden and Perron, 2013). Unlike the non-linear cases, when $n=1$, stretched and consumed channel reaches do not occur, and there is a 1-to-1 mapping between the tectonic uplift history and the river long profile. For this reason, so far, only analytic solutions that assume slope-incision linearity $(n=1)$ were applied as part of forward (Steer, 2021) and inverse models (for a recent review see, Goren et al., 2021) of tectonically forced fluvial landscape evolution.

70 However, while some field studies support the linearity assumption (e.g., Wobus et al. 2006, Ferrier et al. 2013; Schwanghart and Scherler 2020), a growing body of work show that $n$ could be different than unity (Whipple et al., 2000; Harkins et al., 2007; Lague, 2014; Harel et al., 2016). Particularly, significant incision thresholds and relatively small discharge variability are expected to lead to $n>1$ (Anthony and Granger, 2007; Ouimet et al., 2009; Dibiase et al., 2011; Lague, 2014). The current study addresses this gap by developing a simple analytic description of the evolution of channel

75 long profile for the cases where channel reaches may be consumed, namely, $U(t)$ is a staircase decreasing function and $n<1$, or $U(t)$ is a staircase increasing function and $n>1$. The latter scenario is particularly applicable for tectonically active and rejuvenated landscapes. Unlike previous analytic explorations (e.g., Luke, 1972; Weissel and Seidl, 1998; Royden and Perron, 2013) that solved for the long profile as a whole, the current analysis focuses on knickpoint kinematics in a Lagrangian perspective that follows the knickpoint along their migration path. With this approach we develop a criterion for

80 knickpoint preservation and merging, a simple and easy implement forward analytic model, and a linear inverse model constrained by knickpoint preservation. The current study focuses on the analytic derivations and their implications, intentionally leaving field applications to future studies.

\section{Theoretical background}

The SPIM model, equation (1) predicts that for channel segments that erode at the uniform rate (in space and time), the 85 channel slope scales as a power-law function of the drainage area (Wobus et al., 2006; Cyr et al., 2010):

$\frac{\partial z}{\partial x}=k_{\mathrm{s}} A^{-\theta}$,

where $\theta=m / n$ and $k_{\mathrm{s}}=(E / K)^{1 / n}\left(\mathrm{~L}^{2 m / n}\right)$ are commonly referred to as the channel concavity and steepness indices, respectively (Wobus et al., 2006). An alternative perspective to equation (3) emerges when integrating it along the channel, 
while assuming constant $E / K$. Following such an integration, a linear relation emerges between the elevation, $z$, and the

$z(x)=z_{b}+\left(\frac{E}{K A_{0}^{m}}\right)^{\frac{1}{n}} \chi(x)$

$\chi(x)=\int_{x_{b}}^{x}\left(\frac{A_{0}}{A\left(x^{\prime}\right)}\right)^{m / n} d x^{\prime}$

where $z_{\mathrm{b}}$ is the base-level elevation, and the factor $A_{0}\left(\mathrm{~L}^{2}\right)$ is introduced to maintain the $\chi$ dimensions to length. The parameter $\chi$ depends only on the drainage area distribution along the channel, which can easily be calculated for any $m / n$ as part of basic morphometric analysis (Perron and Royden, 2013). When setting $A_{0}=1 \mathrm{~L}^{2}$, the slope of the $\chi-z$ plot becomes channel steepness index, $k_{\mathrm{s}}$.

Under steady-state conditions, when $d z / d t=0$ and $E=U$, the SPIM steepness index becomes a function of the tectonic uplift rate:

$k_{\mathrm{s}}=(U / K)^{1 / n}$,

100 When $U$ varies in time, equation (6) can be used to express transient conditions, where a channel segment is eroding at a rate that corresponds to some previous uplift rate, $U_{\mathrm{p}}$ (Niemann et al., 2001; Goren et al., 2014). In this case, its steepness index could be expressed as:

$k_{\mathrm{s} \_\mathrm{p}}=\left(U_{\mathrm{P}} / K\right)^{1 / n}$,

\section{Slope-break knickpoint migration}

105 A slope-break knickpoint occurs when there is an abrupt change in the slope and steepness index along a channel long profile (Haviv et al., 2010). Within the scope of the SPIM, slope-break knickpoints are commonly associated with a step change in the tectonic uplift rate. When the rate increases, the slope and steepness index below the knickpoint are greater, and the slope-break is convex upward. When the rate decreases, the slope and steepness index below the knickpoint are smaller, and the slope-break would appear as a concave kink along the overall concave channel profile. In this latter case,

110 alluviation might occur below the knickpoint and the assumption of detachment-limited conditions might be violated. This behaviour is beyond the scope of the current analysis. Also outside of the scope of the current study, are the cases of 'stretch zones' ( $U$ increases and $n<1$, and, $U$ decreases and $n>1$ ) (Royden and Perron, 2013).

To predict the retreat rate of slope-break knickpoints, we develop a model based on long profile linearization in the proximity of the knickpoint as shown in Figure 1. 
115 Figure 1a shows the predicted channel profile evolution following a step increase in the rock uplift rate from $U_{0}$ to $U_{1}$ and $n>1$. The figure emphasizes that below and above the knickpoint, the channel segments erode at rates that correspond to the new $\left(U_{1}\right)$ and old $\left(U_{0}\right)$ uplift rates, respectively, and their corresponding steepness indices are $k_{S_{-} 1}=\left(U_{1} / K\right)^{1 / n}$ and $k_{S_{-} 0}=\left(U_{0} / K\right)^{1 / n}$. Figure $1 \mathrm{~b}$ shows the linearized channel segments near the knickpoint. The river profile varies from $z_{t}$ to $z_{t+d t}$ during time step $d t$, accompanied by the knickpoint migrating from point A to D. Segment DG represents the vertical change in knickpoint location, and it can be expressed as:

$\mathrm{DG}=z_{t+d t}(x+d x)-z_{t+d t}(x)=\left(\frac{\partial z}{\partial x}\right)_{1} \cdot v_{\mathrm{H}} \cdot d t$

where $v_{\mathrm{H}}$ is the horizontal velocity for the knickpoint retreat (hereafter, knickpoint celerity). Figure $1 \mathrm{~b}$ shows that:

$D G=D B+B G$,

Where DB is a function of the difference between present uplift rate $\left(U_{1}\right)$ and previous river incision rate, $U_{0}$ :

$\mathrm{DB}=\left(U_{1}-U_{0}\right) \cdot d t$

The segment $\mathrm{BG}$ is the elevation difference between points $\mathrm{A}$ and $\mathrm{B}$ :

$\mathrm{BG}=\left(\frac{\partial z}{\partial x}\right)_{0} \cdot v_{\mathrm{H}} \cdot d t$

Combining equations (8-11), we solve for the knickpoint celerity:

$v_{\mathrm{H}}=\frac{\left(U_{\mathrm{f}}-U_{\mathrm{i}}\right)}{\left(\frac{\partial z}{\partial x}\right)_{1}-\left(\frac{\partial z}{\partial x}\right)_{0}}$,

130 which resembles the derivation of Whipple and Tucker (1999). Assigning equations (1, 6-7) into (12), $v_{\mathrm{H}}$ can be re-written as:

$v_{\mathrm{H}}=\frac{K\left(k_{\mathrm{S}_{1}-1}^{n} k_{\mathrm{S}_{0} 0}^{n}\right)}{\left(k_{\mathrm{S}_{-} 1}-k_{\mathrm{S}_{-} 0}\right)} A^{m / n}=\frac{k_{\mathrm{S}_{1}}^{n}\left(1-\gamma_{0_{-} 1}^{n}\right)}{k_{\mathrm{S}_{-} 1}\left(1-\gamma_{0_{-}}\right)} K A^{m / n}=\frac{k_{\mathrm{S}_{-}}^{n-1}\left(1-\gamma_{0_{-} 1}^{n}\right)}{\left(1-\gamma_{0_{-}}\right)} K A^{m / n}$,

where $\gamma_{0 \_1}=k_{\mathrm{S}_{-} 0} / k_{\mathrm{S}_{-} 1}$. Accordingly, the fluvial response time, $\tau\left(x_{p}\right)$ is expressed as:

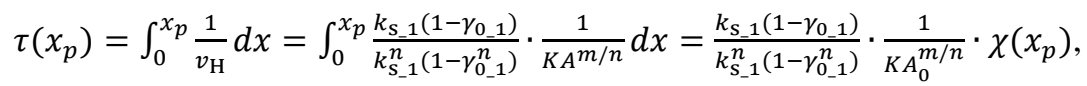

The response time is the time for a perturbation, e.g., a knickpoint, to propagate from the river outlet $(x=0)$ to its present

135 location $x_{p}$. Alternatively, $\tau\left(x_{p}\right)$, can also be thought of as the knickpoint age (Gallen and Wegmann, 2017), or the time before the present when the knickpoint formed at the river outlet.

Importantly, equations (8-14) are developed for the migration of a single knickpoint based on a Lagrangian perspective, i.e., in the reference frame of the migrating knickpoint. Accordingly, equations (13-14) predict that knickpoint celerity and response time depend only on the steepness indices immediately above and below the knickpoint and are independent of the 140 steepness indices at lower reaches below lower, newer knickpoints. This means that as long as knickpoints are not merging, 
as discussed in the following section, knickpoints celerity and response time are not affected by later changes in the tectonic uplift rate and channel steepness.

Equations (13-14) reveal that knickpoint dynamics depends on both the slope exponent, $n$, and the steepness ratios, $\gamma$. Notably, although the derivations in this section are based on convex-up knickpoint (increasing $U$ and $n>1$ ), equations (12-

145 14) are valid also for concave knickpoints (decreasing $U$ and $n<1$, see details in supplementary Text S1). For $n=1$, $v_{\mathrm{H}}$ and $\tau\left(x_{p}\right)$ are independent of the steepness indices and their ratio. Supplementary Text S2 compares the current derivation to previous models of knickpoint celerity (Rosenbloom and Anderson, 1994; Weissel and Seidl, 1998; Oskin and Burbank, 2007; Castillo et al., 2017).

\section{Knickpoint preservation and merging}

150 When more than a single knickpoint propagates upstream a channel profile and $n \neq 1$, the sensitivity of knickpoint celerity to $k_{\mathrm{s}}$ and $\gamma$ leads to potentially complex interactions between the knickpoints. Considering the case of $n>1$ and two knickpoints that formed by two step-increase in tectonic uplift rate: $\mathrm{kp}_{1}$ formed when $U_{0}$ changed to $U_{1}$ and $\mathrm{kp}_{2}$ formed when $U_{1}$ changed to $U_{2}\left(U_{2}>U_{1}>U_{0}\right)$, then the celerity of knickpoint $\mathrm{kp}_{2}$ is larger than that of $\mathrm{kp}_{1}$, and the distance between them gradually decreases (see detailed demonstration in Appendix A). Consequently, depending on the knickpoints relative celerity and the channel length, $\mathrm{kp}_{2}$ can eventually reach $\mathrm{kp}_{1}$, and the two knickpoints merge (referred to as consuming knickpoint in Royden and Perron, 2013). To elucidate knickpoint merging dynamics, we derive an expression for the time of knickpoint merging. Assuming that $\mathrm{kp}_{1}$ formed at time $t=0$ and that $\mathrm{kp}_{2}$ formed at time $t=\mathrm{T}_{1}$, equation (14) is used to express the $\chi$ values of the two knickpoints at any time $\mathrm{T}_{2}>\mathrm{T}_{1}$ as:

$\chi\left(\mathrm{kp}_{2}\right)=\mathrm{T}_{2} K \frac{k_{s_{-} 2}^{n}\left(1-\gamma_{1-2}^{n}\right)}{k_{\mathrm{S}_{-} 2}\left(1-\gamma_{1-2}\right)}$, and $\chi\left(\mathrm{kp}_{1}\right)=\left(\mathrm{T}_{2}+\mathrm{T}_{1}\right) K \frac{k_{s_{-} 1}^{n}\left(1-\gamma_{0_{-}-1}^{n}\right)}{k_{\mathrm{S}_{-} 1}\left(1-\gamma_{0_{-}}\right)}$

160 where $\gamma_{1 \_2}=k_{\mathrm{s}_{-} 1} / k_{\mathrm{S}_{-} 2}$. Knickpoints merging occur at time $\mathrm{T}_{2 \_\mathrm{m}}$ when $\chi\left(\mathrm{kp}_{1}\right)=\chi\left(\mathrm{kp}_{2}\right)$. The ratio $\mathrm{T}_{2 \_\mathrm{m}} / \mathrm{T}_{1}$ is expressed as:

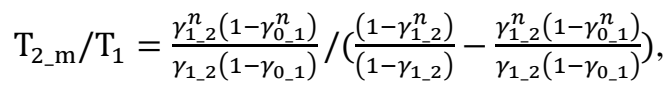

Equation (16) predicts that the timing of knickpoint merging depends on the ratios of channel steepness indices but not on steepness indices themselves. We present a detailed description of the relationship between $T_{2 \_} m / T_{1}$, slope exponent, and the steepness ratios (Figure 2 and 3).

165 Figure 2 shows the results for convex-up consuming knickpoints $(n>1$ and increasing $U)$. When $\gamma_{1 \_2}=\gamma_{0 \_}$, the ratio $T_{2 \_} m / T_{1}$ decreases with $n$ (Figure S2a). This means that a higher slope exponent reduces the life expectancy of knickpoints. Figure 2a also shows that for a constant $n$, lower steepness indices ratio leads to lower $T_{2 \_} / T_{1}$. To explore the dependency of $T_{2 \_} / T_{1}$ on $\gamma_{1 \_}$and $\gamma_{0_{-} 1}$, we fix $n=2$ and vary each of the steepness ratios independently (Figure $2 \mathrm{~b}-\mathrm{c}$ ). Comparing figures $2 \mathrm{~b}$ and $2 \mathrm{c}$, 
it is found that $T_{2 \_} / T_{1}$ is more sensitive to $\gamma_{1 \_2}$ than to $\gamma_{0_{-} 1}$, indicating that the celerity of the younger knickpoint has a greater control over the timing of knickpoint merging.

For the case of concave-up consuming knickpoints $\left(n<1\right.$ and decreasing $U$ ), figure 3a shows that the ratio $\mathrm{T}_{2 \_} / \mathrm{T}_{1}($ when $\left.\gamma_{1 \_}=\gamma_{0 \_}\right)$increases with increasing $n$, and for a constant $n$, a higher steepness ratio leads to a higher $\mathrm{T}_{2 \_} \mathrm{m} / \mathrm{T}_{1}$ ratio. This means that a lower uplift rate, $U_{2}$ (with a lower steepness index below knickpoint $\mathrm{kp}_{2}$ ) leads to a shorter time to knickpoint merging $\mathrm{T}_{2 \_} \mathrm{m}$. In Figures $3 \mathrm{~b}-\mathrm{c}, n$ is fixed at 0.5 , and the steepness ratios change. Here as well, an inverse dependency is observed with respect to the convex slope-break knickpoints, showing that $T_{2 \_} / T_{1}$ is more sensitive to $\gamma_{0_{-} 1}$ than to $\gamma_{1_{-}}$, indicating that the preservation time of $\mathrm{kp}_{1}$ is more sensitive to its own celerity than to that of the younger knickpoint.

We note that when $n=1, \chi\left(\mathrm{kp}_{1}\right)>\chi\left(\mathrm{kp}_{2}\right)$ always holds, indicating that within the framework of the linear SPIM, knickpoints are always preserved and merging cannot occur.

Upon knickpoint merging, only a single knickpoint propagates along the channel, and the steepness indices above and below

the knickpoint correspond to $k_{\mathrm{s}_{-} 0}$ and $k_{\mathrm{s}_{-} 2}$, respectively. Based on equation (13), the instantaneous merged knickpoint celerity becomes:

$v_{\mathrm{H}_{-} \text {after_merger }}=\frac{\left.k_{\mathrm{S}_{2}\left(1-\gamma_{0 \_}\right)}^{n}\right)}{k_{\mathrm{S}_{-} 2}\left(1-\gamma_{0 \_}\right)} K A\left(x_{p}\right)^{m / n}$,

where $\gamma_{0_{-} 2}=k_{\mathrm{S}_{-} 0} / k_{\mathrm{s}_{-} 2}$. The channel reach that used to stretch between the two knickpoints is fully consumed, and the channel profile holds no record of $U_{1}$. Consequently, evaluating the merged knickpoint age by using equation (14) and the steepness indices above and below the merged knickpoint does not yield a meaningful answer. The reason is that upon merging, the steepness indices above and below the merged knickpoint change. Critically, the channel profile does not hold any clue for the event of knickpoint merging, and the river profile would be indistinguishable from a case of a single step increase in uplift rate from $U_{0}$ to $U_{2}$.

\section{A forward analytic model for knickpoint and channel long profile evolution}

190 The elevation change of slope-break knickpoint, $z(t, x)=z\left[t, x=x_{p}(t)\right]$, formed by a step-increase in uplift rate from $U_{0}$ to $U_{1}$, can be expressed as:

$\frac{d z}{d t}=\frac{\partial z}{\partial t}+\frac{\partial z}{\partial x} \frac{d x}{d t}$

where $\frac{d x_{p}(t)}{d t}=v_{\mathrm{H}}$ is the knickpoint celerity. Combining equations (2), (13) and (18) yields:

$\frac{d z\left(t, x_{p}(t)\right)}{d t}=U(t)-K A^{m}\left(k_{\mathrm{s}_{-} 1} A^{-\frac{m}{n}}\right)^{n}+k_{\mathrm{S}_{1} 1} A^{-\frac{m}{n}} \frac{k_{\mathrm{S}_{-} 1}^{n}\left(1-\gamma_{0_{-}-1}^{n}\right)}{k_{\mathrm{S}_{-} 1}\left(1-\gamma_{0_{-}}\right)} K A^{\frac{m}{n}}=U(t)-U_{1}+U_{1} \frac{\left(1-\gamma_{0_{-} 1}^{n}\right)}{\left(1-\gamma_{0_{-}}\right)}$,

195 Integrating equation (19) to solve for the knickpoint elevation leads to: 
$z\left(t, x_{p}(t)\right)=\int_{0}^{t}\left[U\left(t^{\prime}\right)-U_{1}+U_{1} \frac{\left(1-\gamma_{0 \_}^{n}\right)}{\left(1-\gamma_{0 \_}\right)}\right] d t^{\prime}$

As long as knickpoints do not merge, the second and third terms of the integrand in equation (20) are time invariant, and the elevation of the knickpoint could be more simply expressed as:

$\left.z\left(t, x_{p}(t)\right)=\int_{0}^{t} U\left(t^{\prime}\right) d t^{\prime}+\left[\frac{\left(1-\gamma_{0}^{n}\right)}{\left(1-\gamma_{0}-1\right.}\right)-1\right] \cdot U_{1} \cdot t$

200 Equation (21) predicts the elevation of knickpoints for all values of $n$, as the sum of the time integral over the uplift rate history and a time independent term that depends on the steepness indices ratio. When $n=1$, equation (21) reduces to become a function of the uplift history only (Goren et al. 2014), $z\left(t, x_{p}(t)\right)=\int_{0}^{t} U\left(t^{\prime}\right) d t^{\prime}$.

Next, we combine equation (21), which is conditioned by knickpoint preservation, with equation (16) that predicts the duration of preservation to generate a piecewise solution for knickpoint elevation beyond merging. We consider the case of two knickpoints, $\mathrm{kp}_{1}$ and $\mathrm{kp}_{2}$, generated by two step-increase of $U_{2}>U_{1}>U_{0}$, and $n>1$. The time of merging, $\mathrm{T}_{2 \_} \mathrm{m}$, is constrained by equation (16). For any $t<\mathrm{T}_{2 \_} \mathrm{m}+\mathrm{T}_{1}$, the elevations of $\mathrm{kp}_{1}$ and $\mathrm{kp}_{2}$ is predicted by equation (21), when assigning the knickpoint ages, $t=\tau\left(x_{p}\right)$, which corresponds to the time since the change in $U(t)$ that generated the knickpoint. Upon merging, when $t>\mathrm{T}_{2 \_} \mathrm{m}+\mathrm{T}_{1}$, the elevation of the merged knickpoint, $z_{\mathrm{kp} \_12}$, with respect to the formation time of $\operatorname{kp}_{1}(t=0)$ can be expressed as:

$z_{\mathrm{kp} \_12}=z_{1}\left(\mathrm{~T}_{2 \_\mathrm{m}}+\mathrm{T}_{1}\right)+z_{12}$ or $z_{\mathrm{kp} \_12}=z_{2}\left(\mathrm{~T}_{2 \_\mathrm{m}}+\mathrm{T}_{1}\right)+z_{12}$,

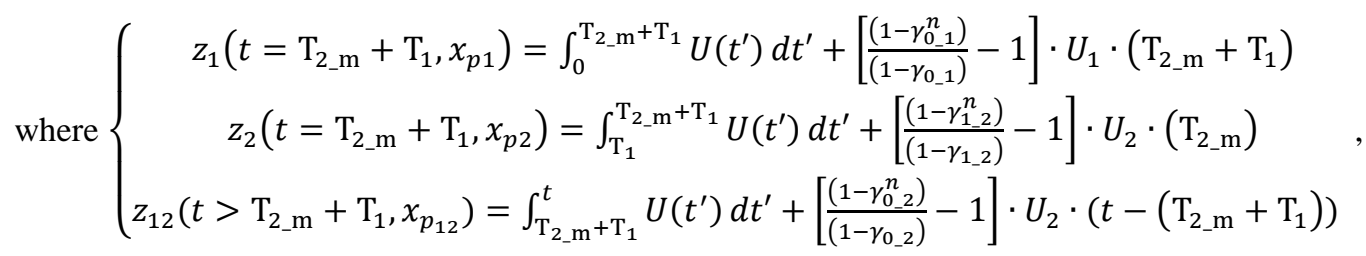

Before merging, the horizontal position of the knickpoints can be expressed as the inverse of equation (14):

$x_{p}(t)=\chi^{-1}\left[K A_{0}^{m / n} t \frac{k_{s_{1}}^{n}\left(1-\gamma_{0-1}^{n}\right)}{k_{S_{-} 1}\left(1-\gamma_{0_{-}}\right)}\right]$,

where again, $t=\tau\left(x_{p}\right)$, is the knickpoint age. After merging, for $t>\mathrm{T}_{2 \_\mathrm{m}}+\mathrm{T}_{1}$

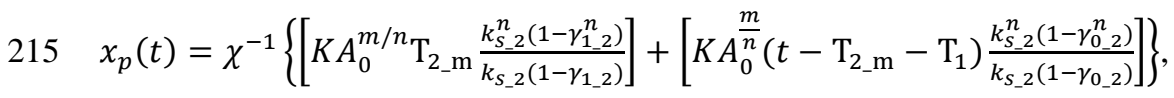

While equations (22-25) present a simple case of two merging knickpoints, it is possible to use equation (16) to calculate the timing and order of several knickpoint merging, including the merger of already merged knickpoints, and to develop a tailored piece-wise analytic solution for their elevation. 
When deriving an analytic solution for the channel long profile as a function of time, equations (21-23) are used for knickpoint elevation, equations (24-25) are used for the knickpoint $x$-positions, and equation (14) is used for the knickpoint $\chi$ values. The channel profile between knickpoints is represented in the $\chi$ - $z$ domain as a linear line connecting the knickpoints. To illustrate long-profile and knickpoint time evolution before and after knickpoint merging and to demonstrate the validity of the analytic forward model, Figure 4 shows the consistence between the analytic solution and a 1-D upwind first-order finite-difference solver of equation (2), for a channel that experiences two step-increases in $U$.

\section{An inverse model to estimate tectonic uplift rate history}

Here, the analytic solution for knickpoint evolution is used to derive a linear inverse model for retrieving the tectonic uplift history from river long profile. The inverse model relaxes the critical assumption of $n=1$ that was a precondition for previous linear inverse models (Goren et al. 2021) and allows inferring the uplift history for any value of $n$, under two assumptions: First, if $n>1, U(t)$ is a monotonically increasing staircase function and if $n<1, U$ is decreasing. Second, all

230 the knickpoints are preserved within the time resolved by the model. The model is based on the block uplift assumption, whereby a suite of basins and tributaries experience and respond to the same time-dependent tectonic history $U(t)$. The model infers the best fit $U(t)$ based on the long profiles of the tributaries and basins.

Changes in $U$ through time emerge as a series of knickpoints with elevations and $\chi$ values, $\left(z_{1}, \chi_{1}\right),\left(z_{2}, \chi_{2}\right), \ldots\left(z_{q-1}, \chi_{q-1}\right)$, which are duplicated across the tributaries and basins. The basin outlets are at $\left(z_{0}=0, \chi_{0}=0\right)$ and the highest $\chi$ channel head is identified with $\left(z_{q}, \chi_{q}=\chi_{\max }\right)$. The knickpoints are used to divide the $\chi-z$ space into segments. Segment $j$, between $\left(\chi_{j-1}, \chi_{j}\right)$, is characterized by a uniform steepness index that shaped the river profile during time interval $\left(t_{j-1}, t_{j}\right)$, where time $t_{j}$ is the age of knickpoint $j$. Knickpoint ages can be constrained from equation (15), and the uplift rate responsible for the formation of each knickpoint can be constrained based on the steepness index below the knickpoints by using equation (7). Consequently, a full uplift history, with discrete step-increase can be derived.

240 A difficulty may arise because $t_{\mathrm{j}}$ in equation (15) and $U_{\mathrm{j}}$ in equation (8) depend on the erodibility, $K$, whose value is commonly poorly constrained. Thus, following Goren et al. (2014), we present a $K$-independent version for the knickpoint age and uplift rate. Scaling equations (15) and (8) by an erosion rate scale factor, $K A_{0}^{m / n} \frac{k_{s_{-} j}^{n}\left(1-\gamma_{j}^{n}\right)}{k_{s_{-} j}\left(1-\gamma_{j}\right)}$, (L/T), a $K$-independent scaled time and a non-dimensional uplift rate are defined:

$t_{j}^{*}=t_{j} \cdot K A_{0}^{m / n} \cdot \frac{k_{s_{-} j}^{n}\left(1-\gamma_{j}^{n}\right)}{k_{\mathrm{s}_{-} j}\left(1-\gamma_{j}\right)}=\chi_{j}$

$245 \quad U_{j}^{*}=A_{0}^{-m / n} k_{\mathrm{s}_{-} j}=A_{0}^{-m / n} \cdot\left(U_{j} / K\right)^{1 / n}$, 
Equations (26-27) produce a non-dimensional uplift rate history, $\left(U_{j}^{*}, t_{j}^{*}\right)$, without any prior information on $K$, as long as it is spatially uniform.

We propose the following steps for the application of the inverse model. First, the data of basins and tributaries is considered in the $\chi$-z domain, where it is divided into $q$ segments along the $\chi$ space, $\chi_{j}(j=0,1,2, \ldots q)$. The division points are considered to be slope-break knickpoints that formed in response to a step-increase in uplift rate. The scaled age of the knickpoints is solved based on equation (26) as $t_{j}^{*}=\chi_{j}$. Second, linear regression is applied in the $\chi$-z domain, independently for each segment. The slope of the regression is identified as $k_{\mathrm{s}_{-} j}$, from which $U_{j}^{*}$ can be derived based on equation (27). Third, conversion from $\left(U_{j}^{*}, t_{j}^{*}\right)$ to a dimensional history $\left(U_{j}, t_{j}\right)$ by solving equations (26-27), after $K$ and $n$ are independently constrained (e.g. Dibiase et al., 2010; Ma et al., 2020).

255 The first step of dividing the $\chi-z$ domain into segments calls for some consideration. First, calculating the $\chi$ value requires calibrating for the concavity, $m / n$. We propose a tributary and basin collapse approach (e.g., Perron and Royden, 2013; Goren et al., 2014; Shelef et al., 2018) or the disorder approach (e.g., Hergartena et al., 2016; Gaillton et al., 2021) that finds the $\mathrm{m} / \mathrm{n}$ that minimizes the scatter in the $\chi-\mathrm{z}$ domain. Second, segment division should ideally be based on division points that represent true slope-break knickpoints. Many algorithms have been previously proposed to identify slope-break knickpoints (e.g., Mudd et al., 2014). Here, we suggest a different approach that rely on the simplicity and efficiency of the inverse model. The inversion procedure could be run many times, while choosing the division points randomly. Inversion results could be evaluated by comparing the measured profiles and the profile predicted by our forward model. The quality of the solution with a specific number and location of division points could be evaluated based on an optimization criterion, such as a misfit. Here, we consider a misfit function that penalizes models with more knickpoints (more parameters) for their excess complexity:

misfit $=\frac{1}{N / M} \sqrt{\sum_{i=1}^{N}\left(z_{i}-\widetilde{z_{l}}\right)^{2}}$

where $\mathrm{z}_{\mathrm{i}}$ and $\widetilde{z_{\iota}}$ are the measured and predicted elevations at pixel $i$, respectively. $N$ is the total number of data along the river long profiles, and $M=q$ is the number of division points, or the number of parameters.

To demonstrate the applicability of the inverse method, we use a low resolution numerical model (which suffers from numerical diffusion) to generate ten river profiles with variable channel length and drainage area distribution. These rivers respond to the same uplift rate history, with two step-increases in the rate forming two knickpoints in each profile. Knickpoints do not merge over the timeframe of $U(\mathrm{t})$ application (Figure 5a and $\mathrm{b}$ ). To artificially increase the noise in the data, the elevations are perturbed by random errors (equation 29):

$\widehat{z_{l}}($ perturbed $)=z_{i-1}+\left(z_{i+1}-z_{i-1}\right) * \operatorname{rand}(1)$, 
275 where rand(1) is a random number between 0 and 1. Inversion in applied to the data with 1-6 division points. For each number of division points, 5000 realizations of the inversion model were performed with different random position of the division points. Figure 5c shows the minimal misfit (equation 28) achieved for each number of division points, indicating that the best fit solution has division points corresponding to the two knickpoints. Figure $5 \mathrm{~d}$ compares between the applied and inferred histories, showing that the 2 division points inversion correctly infers the applied history.

\section{Discussion and conclusion}

The current analysis explores river long profile evolution in response to temporal step-changes in the tectonic rock uplift rate $U(t)$ and a non-unity slope exponent, leading to consuming channel segments (Royden and Perron, 2013) and merging knickpoints. The approach we adopt here, of resolving knickpoint kinematics in a Lagrangian frame of reference, allows us to constrain the timing of knickpoint merging and the elevation of knickpoint before and after merging. The finding that despite channel reach consumption, knickpoint celerity depends only on the channel steepness below and above the knickpoint, allow us to develop a piece-wise analytic solution that represents the evolution of knickpoints and channel long profile through time, before and after knickpoint merging.

Analytic solutions of long profile evolution can significantly expedite forward and inverse tectonic - fluvial landscape evolution. However, so far, analytic solutions were used in such models only under linear assumption (Pritchard et al., 2009;

290 Fox et al. 2014; Goren et al., 2014, 2021; Rudge et al., 2015; Steer et al. 2021). The simple analytic derivation that we present here can expand the domain of parameters for which analytic solutions are used in such models, by including new geomorphic scenarios with $n \neq 1$ (with the restriction of increasing $U(t)$ for $n>1$ and decreasing $U(t)$ for $n<1$ ). For example, inverse models that are based on Bayesian statistics (Fox et al., 2015; Gallen and Fernández-Blanco, 2021), which have gain recent popularity could become significantly more efficient and accurate when the forward model is represented 295 with an analytic solution.

The knickpoint merging analysis further emphasizes a critical property of the links between tectonic and long profile evolution when $n \neq 1$. Each tectonic history is associated with a single, well-defined river profile at any given time. However, any particular river profile could be generated by infinitely many tectonic histories. All histories except for one lead to knickpoint merging dynamics. The linear inverse model that we develop here finds the single history for which all 300 knickpoint are preserved. While this inverse approach is highly restrictive, it finds the correct solution when only a single knickpoint exists in the data. We further suggest that when a small number of knickpoint groups is identified in the data, the solution of this simple inverse model could still be highly informative as a preliminary guess for the tectonic history that shaped the fluvial landscape. 


\section{Appendix A: A mathematical demonstration of knickpoint merging}

In this section, we show that two knickpoints formed with $n>1$ and step increases in $U$ must eventually merge. The two knickpoints are denoted by $\mathrm{kp}_{1}$, which was formed by an uplift rate increase from $U_{0}$ to $U_{1}$, and $\mathrm{kp}_{2}$ formed by an increase from $U_{1}$ to $U_{2}\left(U_{2}>U_{1}>U_{0}\right)$. The celerity of the two knickpoints is expressed by equation (13):

$v_{\mathrm{H}_{-} \mathrm{kp} 1}=\frac{k_{\mathrm{S}_{-}}^{n-1}\left(1-\gamma_{0 \_}^{n}\right)}{\left(1-\gamma_{0 \_}\right)} K A\left(\mathrm{kp}_{1}\right)^{m / n}$, and $v_{\mathrm{H}_{-} \mathrm{kp} 2}=\frac{k_{S_{-} 2}^{n-1}\left(1-\gamma_{1 \_}^{n}\right)}{\left(1-\gamma_{1 \_}\right)} K A\left(\mathrm{kp}_{2}\right)^{m / n}$,

Since $\mathrm{kp}_{2}$ is located below to $\mathrm{kp}_{1}, A\left(\mathrm{kp}_{2}\right)$ is larger than $A\left(\mathrm{kp}_{1}\right)$. Next, it is left to show that $\frac{k_{S_{-}}^{n-1}\left(1-\gamma_{1 \_2}^{n}\right)}{\left(1-\gamma_{1-2}\right)}>\frac{k_{S_{-}}^{n-1}\left(1-\gamma_{0 \_}^{n}\right)}{\left(1-\gamma_{0-1}\right)}$. We

310 define a variable:

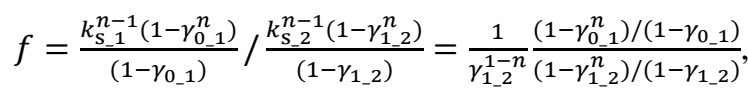

Because $n>1$, we can re-write $n=\alpha / \beta$, where $\alpha>\beta>1$ and $\alpha$ and $\beta$ are both integers. Thus,

$f=\frac{1}{\gamma_{1 \_}^{1-\alpha / \beta}} \frac{\left(1-\left(\gamma_{01}^{1 / \beta}\right)^{\alpha}\right) /\left(1-\left(\gamma_{0}^{1 / \beta}\right)^{\beta}\right)}{\left(1-\left(\gamma_{1 \_}^{1 / \beta}\right)^{\alpha}\right) /\left(1-\left(\gamma_{1 \_}^{1 / \beta}\right)^{\beta}\right)}=\frac{f_{\text {nume }}}{f_{\text {deno }}}$,

where $f_{\text {nume }}$ and $f_{\text {deno }}$ are the numerator and denominator of $f$, respectively. We use the method of polynomial division:

$315\left\{\begin{array}{c}1-\left(\gamma_{0_{-} 1}^{1 / \beta}\right)^{\alpha}=\left(1-\gamma_{0_{-} 1}^{1 / \beta}\right)\left(\left(\gamma_{0_{-}}^{1 / \beta}\right)^{\alpha-1}+\cdots+\left(\gamma_{0_{1}}^{1 / \beta}\right)^{\beta}+\cdots+\left(\gamma_{0_{-} 1}^{1 / \beta}\right)^{0}\right) \\ 1-\left(\gamma_{0_{-} 1}^{1 / \beta}\right)^{\beta}=\left(1-\gamma_{0_{-} 1}^{1 / \beta}\right)\left(\left(\gamma_{0_{-} 1}^{1 / \beta}\right)^{\beta-1}+\left(\gamma_{0_{-} 1}^{1 / \beta}\right)^{\beta-2}+\cdots+\left(\gamma_{0_{-} 1}^{1 / \beta}\right)^{0}\right)\end{array}\right.$,

Assigning equation (A4) into $f_{\text {nume }}$, we can derive:

$f_{\text {nume }}=\frac{\left(\gamma_{0_{1}}^{1 / \beta}\right)^{\alpha-1}+\cdots+\left(\gamma_{0_{-}}^{1 / \beta}\right)^{\beta}+\cdots+\left(\gamma_{0_{1}}^{1 / \beta}\right)^{0}}{\left(\gamma_{0_{-}}^{1 / \beta}\right)^{\beta-1}+\left(\gamma_{0_{-}}^{1 / \beta}\right)^{\beta-2}+\cdots+\left(\gamma_{0_{-}}^{1 / \beta}\right)^{0}}=\frac{\left(\gamma_{0_{1}}^{1 / \beta}\right)^{\alpha-1}+\left(\gamma_{0_{1}}^{1 / \beta}\right)^{\alpha-2}+\cdots+\left(\gamma_{0_{-}}^{1 / \beta}\right)^{\beta}}{\left(\gamma_{0_{-} 1}^{1 / \beta}\right)^{\beta-1}+\left(\gamma_{0_{-} 1}^{1 / \beta}\right)^{\beta-2}+\cdots+\left(\gamma_{0_{-}}^{1 / \beta}\right)^{0}}+1=\frac{\left(\gamma_{0_{-}}^{1 / \beta}\right)^{\alpha-1-\beta}+\left(\gamma_{0_{1}}^{1 / \beta}\right)^{\alpha-2-\beta}+\cdots+\left(\gamma_{0_{1}}^{1 / \beta}\right)^{\beta-\beta}}{\left(\gamma_{0_{-}}^{1 / \beta}\right)^{-1}+\left(\gamma_{0_{-}}^{1 / \beta}\right)^{-2}+\cdots+\left(\gamma_{0_{-}}^{1 / \beta}\right)^{-\beta}}+1$,

Because $\quad\left(\gamma_{0_{-} 1}^{1 / \beta}\right)^{\alpha-1-\beta}+\left(\gamma_{0_{-} 1}^{1 / \beta}\right)^{\alpha-2-\beta}+\cdots+\left(\gamma_{0_{-}}^{1 / \beta}\right)^{\beta-\beta}<1+1+\cdots+1=\alpha-\beta \quad, \quad$ and $\quad\left(\gamma_{0_{-}}^{1 / \beta}\right)^{-1}+\left(\gamma_{0_{-}}^{1 / \beta}\right)^{-2}+\cdots+$ $\left(\gamma_{0 \_}^{1 / \beta}\right)^{-\beta}>1+1+\cdots+1=\beta$, we can derive:

$f_{\text {nume }}<\frac{\alpha-\beta}{\beta}+1$

Again, we use polynomial division:

$\left\{\begin{array}{l}1-\left(\gamma_{1 \_2}^{1 / \beta}\right)^{\alpha}=\left(1-\gamma_{1 \_}^{1 / \beta}\right)\left(\left(\gamma_{1 \_2}^{1 / \beta}\right)^{\alpha-1}+\left(\gamma_{1 \_2}^{1 / \beta}\right)^{\alpha-2}+\cdots+\left(\gamma_{1 \_}^{1 / \beta}\right)^{0}\right) \\ 1-\left(\gamma_{1 \_2}^{1 / \beta}\right)^{\beta}=\left(1-\gamma_{1 \_2}^{1 / \beta}\right)\left(\left(\gamma_{1 \_2}^{1 / \beta}\right)^{\beta-1}+\left(\gamma_{1 \_2}^{1 / \beta}\right)^{\beta-2}+\cdots+\left(\gamma_{1 \_2}^{1 / \beta}\right)^{0}\right)\end{array}\right.$,

Assigning equation (A7) into $f_{\text {deno }}$, we derived: 
$f_{\text {deno }}=\frac{\left(\gamma_{12}^{1 / \beta}\right)^{\alpha-1}+\left(\gamma_{12}^{1 / \beta}\right)^{\alpha-2}+\cdots+\left(\gamma_{12}^{1 / \beta}\right)^{0}}{\left(\gamma_{1 \_}^{1 / \beta}\right)^{\beta-1}+\left(\gamma_{1 \_2}^{1 / \beta}\right)^{\beta-2}+\cdots+\left(\gamma_{1 \_}^{1 / \beta}\right)^{0}} \cdot\left(\gamma_{1 \_2}^{1 / \beta}\right)^{\beta-\alpha}=\frac{\left(\gamma_{1 \_}^{1 / \beta}\right)^{\beta-1}+\left(\gamma_{1 \_}^{1 / \beta}\right)^{\beta-2}+\cdots+\left(\gamma_{12}^{1 / \beta}\right)^{\beta-\alpha}}{\left(\gamma_{1 \_}^{1 / \beta}\right)^{\beta-1}+\left(\gamma_{1 \_}^{1 / \beta}\right)^{\beta-2}+\cdots+\left(\gamma_{1 \_2}^{1 / \beta}\right)^{0}}$,

or, $f_{\text {deno }}=\frac{\left(\gamma_{1 \_}^{1 / \beta}\right)^{\beta-1}+\left(\gamma_{1 \_2}^{1 / \beta}\right)^{\beta-2}+\cdots+\left(\gamma_{12}^{1 / \beta}\right)^{0}+\left(\gamma_{1 \_2}^{1 / \beta}\right)^{-1}+\left(\gamma_{12}^{1 / \beta}\right)^{-2}+\cdots+\left(\gamma_{12}^{1 / \beta}\right)^{\beta-\alpha}}{\left(\gamma_{1 \_}^{1 / \beta}\right)^{\beta-1}+\left(\gamma_{1 \_}^{1 / \beta}\right)^{\beta-2}+\cdots+\left(\gamma_{1 \_2}^{1 / \beta}\right)^{0}}=\frac{\left(\gamma_{1 \_}^{1 / \beta}\right)^{-1}+\left(\gamma_{1 \_2}^{1 / \beta}\right)^{-2}+\cdots+\left(\gamma_{12}^{1 / \beta}\right)^{\beta-\alpha}}{\left(\gamma_{1 \_}^{1 / \beta}\right)^{\beta-1}+\left(\gamma_{1 \_}^{1 / \beta}\right)^{\beta-2}+\cdots+\left(\gamma_{1 \_}^{1 / \beta}\right)^{0}}+1$,

Because $\left(\gamma_{1 \_2}^{1 / \beta}\right)^{-1}+\left(\gamma_{1 \_2}^{1 / \beta}\right)^{-2}+\cdots+\left(\gamma_{1 \_2}^{1 / \beta}\right)^{\beta-\alpha}>1+1+\cdots+1=\alpha-\beta$, and $\left(\gamma_{1 \_2}^{1 / \beta}\right)^{\beta-1}+\left(\gamma_{1 \_}^{1 / \beta}\right)^{\beta-2}+\cdots+\left(\gamma_{1 \_}^{1 / \beta}\right)^{0}<$ $1+1+\cdots+1=\beta$, we derived:

$f_{\text {deno }}>\frac{\alpha-\beta}{\beta}+1$,

Assigning equations (A6 and A10) into (A3), we can derive:

$f=\frac{f_{\text {nume }}}{f_{\text {deno }}}<\left(\frac{\alpha-\beta}{\beta}+1\right) /\left(\frac{\alpha-\beta}{\beta}+1\right)=1$,

Thus, $v_{\mathrm{H}_{-} \mathrm{kp} 1}<v_{\mathrm{H} \_\mathrm{kp} 2}, \mathrm{kp}_{2}$ always migrates faster than $\mathrm{kp}_{1}$, and given sufficient channel length the two knickpoints will merge. The time of merging is given by equation (16).

\section{Code and data availability}

This study has no complex codes or data sharing issue, because all the figures can be re-produced by solving the related equations.

\section{Author contribution}

Both YW and LG developed these models, conducted the study, and designed structure of the manuscript. YW solved these equations, and wrote the manuscript. LG wrote the 1-D numerical codes and helped to test the analytical derivations. The manuscript was mostly revised, polished, and improved by LG. DZ and HZ provided valuable suggestions and made some revisions.

\section{Competing interests}

The authors declare that they have no conflict of interest.

\section{Acknowledgments}

We thank George E. Hilley for revising the earlier version of this manuscript many times with great patience and stimulating our inspiration in using the method of characteristics to solve the equation. We thank Fiona Clubb, Eitan Shelef, and Sean F. 
Gallen for constructive instructions on an earlier version of this manuscript. This work was supported by the National Science Foundation of China (41802227).

\section{References}

Anthony, D.M., and Granger, D.E.: An empirical stream power formulation for knickpoint retreat in Appalachian Plateau fluviokarst. J. Hydrol. 343: 117-126, 2007.

Baynes, E.R.C., Attal, M., Niedermann, S., Kirstein, L.A., Dugmore, A.J., and Naylor, M.: Erosion during extreme flood events dominates Holocene canyon evolution in northeast Iceland. Proc. Natl. Acad. Sci. U. S. A. 112:2355-2360. http://dx.doi.org/10.1073/pnas.1415443112, 2015.

Bennett, R.A., Wernicke, B.P., Niemi, N.A., Friedrich, A.M., and Davis, J.L.: Contemporary strain rates in the northern Basin and Range Province from GPS data. Tectonics, 22(2), 1008. doi:10.1029/2001TC001355, 2003.

Berlin, M.M., and Anderson, R.S.: Modeling of knickpoint retreat on the Roan Plateau, western Colorado. J. Geophys. Res., 112, F03S06, doi:10.1029/2006JF000553, 2007.

Bishop, P., Hoey, T.B., Jansen, J.D., and Artza, I.L.: Knickpoint recession rate and catchment area: the case of uplifted rivers in Eastern Scotland. Earth Surf. Process. Landf. 30:767-778, 2005.

Bookhagen, B., and Burbank, D.W.: Toward a complete Himalayan hydrological budget: spatiotemporal distribution of snowmelt and rainfall and their impact on river discharge. J. Geophys. Res. 115, F03019, 2010.

Burchfiel, B.C., Hodges, K.V., and Royden, L.H.: Geology of Panamint Valley - Saline Valley pull-apart system, California: palinspastic evidence for low-angle geometry of a Neogene range-bounding fault. J. Geophys. Res. 92, 10,422-410,426, 1987.

365 Castillo, M., Ferrari, L., and Munoz-Salinas, E.: Knickpoint retreat and landscape evolution of the Amatlan de Canas halfgraben (northern sector of Jalisco Block, western Mexico). J. S. A. Earth Sci. 77, 108-122, 2017.

Cook, K.L., Turowski, J.M., and Hovius, N.: A demonstration of the importance of bedload transport for fluvial bedrock erosion and knickpoint propagation. Earth Surf. Process. Landf. 38, 683-695, 2013.

Cyr, A.J., Granger, D.E., Olivetti, V., and Molin, P.: Quantifying rock uplift rates using channel steepness and cosmogenic nuclide-determined erosion rates: Examples from northern and southern Italy. Lithosphere 2(3), 188-198. https://doi.org/10.1130/L96.1, 2010.

DiBiase, R.A., Whipple, K.X., Heimsath, A.M., and Ouimet, W.B.: Landscape form and millennial erosion rates in the San Gabriel Mountains, CA. Earth Planet. Sci. Lett. 289(1): 134-144, 2010.

Duvall, A., Kirby, E., and Burbank, D.: Tectonic and lithologic controls on bedrock channel profiles and processes in coastal California. J. Geophys. Res. 109, F03002, 2004.

Ferrier, K. L., Huppert, K. L., and Perron, J. T.: Climatic control of bedrock river incision. Nature 496(7444), $206-209$. https://doi.org/10.1038/nature11982, 2013. 
Fox, M., Goren, L., May, D.A., and Willett, S.D.: Inversion of fluvial channels for paleorock uplift rates in Taiwan. J. Geophys. Res. Earth 119:1853-1875. http://dx.doi.org/10.1002/2014JF003196, 2014.

Fox, M., Bodin, T., and Shuster, D.L.: Abrupt changes in the rate of Andean Plateau uplift from reversible jump Markov Chain Monte Carlo inversion of river profiles. Geomorphology 238:1-14, 2015.

Gailleton, B., Mudd, S.M., Clubb, F.J., Grieve, S.W.D., and Hurst, M.D.: Impact of changing concavity indices on channel steepness and divide migration metrics. J. Geophys. Res. Earth (submitted), https://doi.org/10.1002/essoar.10505724.1, 2021

385 Gailleton, B., Mudd, S. M., Clubb, F. J., Peifer, D., and Hurst, M. D.: A segmentation approach for the reproducible extraction and quantification of knickpoints from river long profiles, Earth Surf. Dynam. 7, 211-230, https://doi.org/10.5194/esurf-7-211-2019, 2019.

Gallen, S. F., and Fernández-Blanco, D.: A new data-driven Bayesian inversion of fluvial topography clarifies the tectonic history of the corinth rift and reveals a channel steepness threshold. J. Geophys. Res. Earth, 126, e2020JF005651. https://doi.org/10.1029/2020JF005651, 2021.

Gallen, S.F., and Wegmann, K.W.: River profile response to normal fault growth and linkage: an example from the Hellenic forearc of south-central Crete, Greece. Earth Surf. Dyn. 5, 161-186, 2017.

Gasparini, N. M., and Brandon, M. T.: A generalized power law approximation for fluvial incision of bedrock channels, J. Geophys. Res., 116, F02020, doi:10.1029/2009JF001655, 2011.

Goren, L., Fox, M., and Willett, S.D.: Tectonics from fluvial topography using formal linear inversion: theory and applications to the Inyo Mountains, California. J. Geophys. Res. Earth 119:1651-1681, 2014.

Goren, L., Fox, M., and Willett, S. D.: Linear Inversion of Fluvial Long Profiles to Infer Tectonic Uplift Histories, Reference Module in Earth Systems and Environmental Sciences, Elsevier, ISBN 9780124095489, https://doi.org/10.1016/B978-012-818234-5.00075-4, 2021.

Gourmelen, N., Amelung, F., and Lanari, R.: Interferometric synthetic aperture radar-GPS integration: interseismic strain accumulation rates across the Hunter Mountain fault in the eastern California shear zone. J. Geophys. Res. 115, B09408, 2010.

Hack, J.T.: Studies of Longitudinal Stream Profiles in Virginia and Maryland, U.S. Geological Survey Professional Paper 294(B), 97, 1957.

Hack, J.T.: Stream profile analysis and stream-gradient index. Journal of Research of the U.S. Geological Survey 1, 421-429, 1973.

Harel, M.-A., Mudd, S.M., and Attal, M.: Global analysis of the stream power law parameters based on worldwide 10Be denudation rates. Geomorphology 268, 184-196. doi:10.1016/j.geomorph.2016.05.035, 2016.

Harkins, N., Kirby, E., Heimsath, A., Robinson, R., and Reiser, U.: Transient fluvial incision in the headwaters of the Yellow River, northeastern Tibet, China. J. Geophys. Res. Earth 112: F03S04, 2007. 
Haviv, I., Enzel, Y., Whipple, K.X., Zilberman, E., Matmon, A., Stone, J., and Fifield, K.L.: Evolution of vertical knickpoints (waterfalls) with resistant caprock: insights from numerical modelling. J. Geophys. Res. Earth 115 (F3), F03028. http://dx.doi.org/10.1029/2008JF001187, 2010.

Hergarten, S., Robl, J., and Stüwe, K.: Tectonic geomorphology at small catchment sizes-extensions of the stream-power approach and the $\chi$ method. Earth Surf. Dynam. 4, 1-9, 2016.

Hilley, G.E., Porder, S., Aron, F., Baden, C.W., Johnstone, S.A., Liu, F., Sare, R., Steelquist, A., and Young, H.H.: Earth's topographic relief potentially limited by an upper bound on channel steepness. Nat. Geosci. 12: 828-832, 2019.

Howard, A.D., and Kerby, G.: Channel changes in badlands. Geol. Soc. Am. Bull. 94, 739-752, 1983.

Kent, E., Boulton, S.J., Whittaker, A., Stewart, I.S., and Alçiçek, M.C.: Normal fault growth and linkage in the Gediz (Alaşehir) Graben, Western Turkey, revealed by transient river long-profiles and slope-break knickpoints. Earth Surf. Process. Landf. 42, 836-852, 2017.

Kirby, E., Regalla, C., Ouimet, W.B., and Bierman, P.R.: Reconstructing Temporal Variation in Fault Slip from Footwall Topography: An Example from Saline Valley, California. 2010 Fall Meeting, American Geophysical Union, San Francisco, CA, 2010.

Kirby, E., and W. Ouimet: Tectonic geomorphology along the eastern margin of Tibet: Insights into the pattern and processes of active deformation adjacent to the Sichuan basin, in Growth and Collapse of the Tibetan Plateau, Geol. Soc. Lond. Spec. Publ., vol. 353, edited by R. Gloaguen and L. Ratschbacher, pp. 165-188, 2011.

Kirby, E., and Whipple, K.X.: Expression of active tectonics in erosional landscapes. J. Struct. Geol. 44:54-75. http://dx.doi.org/10.1016/j.jsg.2012.07.009, 2012.

430 Lague, D.: The stream power river incision model: evidence, theory and beyond. Earth Surf. Process. Landf. 39, 38-61, 2014. Lamb, M.P., Mackey, B.H., and Farley, K.A.: Amphitheater-headed canyons formed by megaflooding at Malad Gorge, Idaho. Proc. Natl. Acad. Sci. U. S. A. 111:57-62. http://dx.doi.org/10.1073/pnas.1312251111, 2014.

Lavé, J., and Avouac, J.P.: Fluvial incision and tectonic uplift across the Himalayas of central Nepal. J. Geophys. Res. Sol. Ea. 106: 26,561-26,591, 2001.

435 Leopold, L., and Maddock, T.: The hydraulic geometry of stream channels and some physiographic implications. Geol. Surv. Prof. Pap. 252: 1-57, 1953.

Luke, J. C.: Mathematical models for landform evolution. J. Geophys. Res., 77, 2460-2464, 1972.

Ma, Z., Zhang, H., Wang, Y., Tao, Y., and Li, X.: Inversion of Dadu River bedrock channels for the late Cenozoic uplift history of the eastern Tibetan Plateau. Geophys. Res. Lett. 47(4). https://doi.org/10.1029/2019GL086882, 2020.

440 Mackey, B.H., Scheingross, J.S., Lamb, M.P., and Farley, K.A.: Knickpoint formation, rapid propagation, and landscape response following coastal cliff retreat at the last interglacial sea-level highstand: Kaua'i, Hawai'i. Geol. Soc. Am. Bull. 126:925-942. http://dx.doi.org/10.1130/B30930.1, 2014. 
https://doi.org/10.5194/esurf-2021-101

Preprint. Discussion started: 21 December 2021

(c) Author(s) 2021. CC BY 4.0 License.

Mudd, S.M., Attal, M., Milodowski, D.T., Grieve, S.W., and Valters, D.A.: A statistical framework to quantify spatial variation in channel gradients using the integral method of channel profile analysis, J. Geophys. Res. Earth, 119, 138-152, 2014.

Mudd, S.M., Clubb, F.J., Gailleton, B., and Hurst, M.D.: How concave are river channels? Earth Surf. Dynam. 6, 505-523, 2018.

Niemann, J.D., Gasparini, N.M., Tucker, G.E., and Bras, R.L.: A quantitative evaluation of Playfair's law and its use in testing long-term stream erosion models. Earth Surf. Process. Landf. 26 (12), 1317-1332, 2001.

Oskin, M.E., and Burbank, D.: Transient landscape evolution of basement-cored uplifts: example of the Kyrgyz Range, Tian Shan. J. Geophys. Res. 112, F03S03. https://doi.org/10.1029/2006JF000563, 2007.

Ouimet, W.B., Whipple, K.X., and Granger, D.E.: Beyond threshold hillslopes: channel adjustment to base-level fall in tectonically active mountain ranges. Geology 37(7), 579-582. http://dx.doi.org/10.1130/G30013A.1, 2009.

Perron, J.T., and Royden, L.: An integral approach to Bedrock River profile analysis. Earth Surf. Process. Landf. 38:570576. http://dx.doi.org/10.1002/esp.3302, 2013.

Pritchard, D., Roberts, G.G., White, N.J., and Richardson, C.N.: Uplift histories from river profiles. Geophys. Res. Lett., 36, L24301. doi:10.1029/2009GL040928, 2009.

Rosenbloom, N.A., and Anderson, R.S.: Hillslope and channel evolution in a marine terraced landscape, Santa Cruz, California. J. Geophys. Res. 99(B7), 14,013-14,029, 1994.

Royden, L., and Perron, J.T.: Solutions of the stream power equation and application to the evolution of river longitudinal profiles. J. Geophys. Res. Earth 118 (2):497-518. http://dx.doi.org/10.1002/jgrf.20031, 2013.

Rudge, J.F., Roberts, G.G., White, N.J., and Richardson, C.N.: Uplift histories of Africa and Australia from linear inverse modeling of drainage inventories. J. Geophys. Res. Earth 120, 894-914, 2015.

Schwanghart. W., and Scherler, D.: Divide mobility controls knickpoint migration on the Roan Plateau (Colorado, USA). 465 Geology, 48(7). https://doi.org/10.1130/G47054.1, 2020.

Shelef, E., Haviv, I., and Goren, L.: A potential link between waterfall recession rate and bedrock channel concavity. J. Geophys. Res. Earth 123. https://doi.org/10.1002/2016JF004138, 2018.

Snyder, N. P., Whipple, K. X., Tucker, G. E., and Merritts, D.: Landscape response to tectonic forcing: DEM analysis of stream profiles in the Mendocino Triple Junction region, northern California. Geol. Soc. Am. Bull., 112(8), 1250-1263, 2000.

Steer, P.: Short communication: Analytical models for 2D landscape evolution. Earth Surf. Dynam., 9(5), 1239-1250, 2021.

Stock, G.M., Frankel, K.L., Ehlers, T.A., Schaller, M., Briggs, S.M., and Finkel, R.C.: Spatial and temporal variations in denudation of the Wasatch mountains, Utah, USA. Lithosphere 1 (1), 34-40, 2009.

Stock, J.D., and Montgomery, D.R.: Geologic constraints on bedrock river incision using the stream power law. J. Geophys.

Res. Sol. Ea., 104, 4983-4993, 1999. 
Venditti, J.G., Li, G., Deal, E., Dingle, E., and Church, M.: Struggles with stream power: Connecting theory across scales.

Geomorphology, 366, 106817, 2019.

Wang, Y., Zhang, H., Zheng, D., Dassow, W.V., Zhang, Z., Yu, J., and Pang, J.: How a stationary knickpoint is sustained: new insights into the formation of the deep Yarlung Tsangpo Gorge. Geomorphology 285, 28-43, 2017.

Weissel, J. K. and Seidl, M. A.: Inland propagation of erosional escarpments and river profile evolution across the southeast Aus tralian passive continental margin, Geophys. Monogr., 107, 189-206, 1998.

Whipple, K.X., Hancock, G.S., and Anderson, R.S.: River incision into bedrock: Mechanics and relative efficacy of plucking, abrasion, and cavitation. Geol. Soc. Am. Bull. 112, 490-503, 2000.

Whipple, K.X., DiBiase, R.A., and Crosby, B.T.:. Bedrock rivers. In: Shroder, J. (Editor in Chief) and Wohl, E. (Ed.), Treatise on Geomorphology. Academic Press, San Diego, CA, vol. 9, Fluvial Geomorphology, pp. 550-573, 2013.

Whipple, K.X., and Tucker, G.E.: Dynamics of the stream power river incision model: Implications for height limits of mountain ranges, landscape response timescales and research needs, J. Geophys. Res., 104, 17,661-17,674, 1999.

Whipple, K.X., and Tucker, G.E.: Implications of sediment-flux-dependent river incision models for landscape evolution. Journal of Geophysical Research, Solid Earth 107(B2). https://doi.org/10.1029/2000JB000044, 2002.

490 Whitham, G.B.: Linear and Non-Linear Waves. 636 pp., John Wiley, New York, 1974.

Whittaker, A.C., and Boulton, S.J.: Tectonic and climatic controls on knickpoint retreat rates and landscape response times. J. Geophys. Res. Earth. 117: F02024. doi:10.1029/2011JF002157.F02024, 2012.

Willett, S.D., McCoy, S.W., Perron, J.T., Goren, L., and Chen, C.-Y.: Dynamic reorganization of river basins. Science, 343(6175), 1248765. https://doi.org/10.1126/science.1248765, 2014.

495 Wobus, C., Whipple, K.X., Kirby, E., Snyder, N., Johnson, J., Spyropolou, K., Crosby, B., and Sheehan, D.: Tectonics from topography: procedures, promise, and pitfalls. In: Willett, S.D., Hovius, N., Brandon, M.T., Fisher, D.M. (Eds.), Tectonics, Climate, and Landscape Evolution. Geological Society of America Special Paper 398, Penrose Conference Series, pp. 5574, doi: 10.1130/2006.2398(04), 2006.
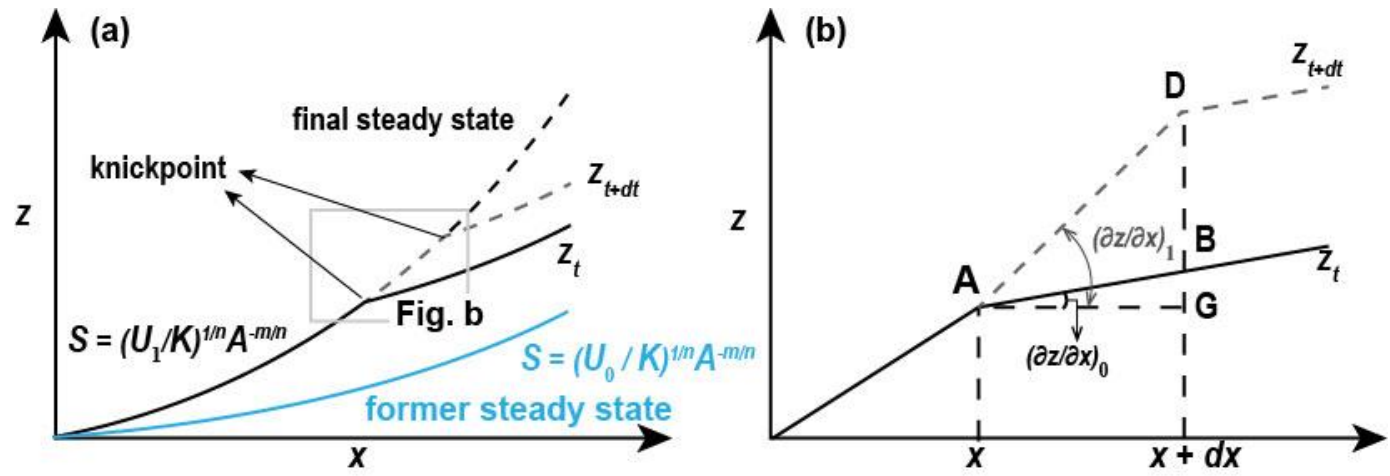
Figure 1: (a) Schematics of a channel profile evolution in response to an increase in the relative uplift rate from $U_{0}$ to $U_{1}$ (revised from Goren et al., 2014). The blue solid line shows the steady-state channel under uplift rate $U_{0}$. The black solid and gray dashed lines show the transient channel at time $t$ and $t+d t$. The black dashed line shows the final steady-state channel under uplift rate $U_{0}$. (b) Schematics of knickpoint retreat (revised from Wang et al., 2017). Points $A$ and $D$ are the knickpoint positions at time $t$ and $t+d t$. Evolution of the channel profile in the time step $d t$ is shown as the transition from $z_{t}$ to $z_{t+d t}$.
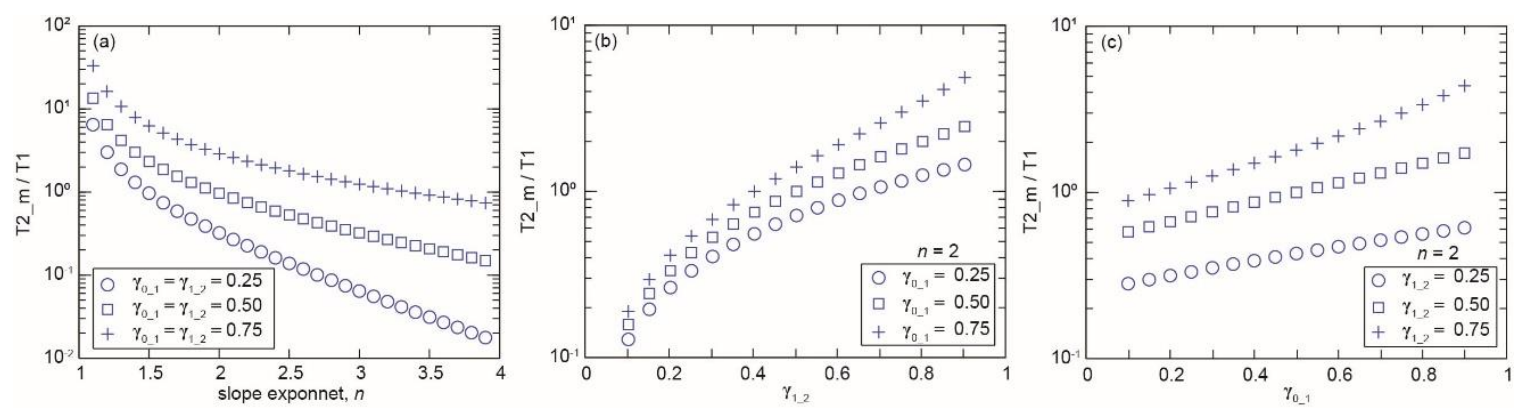

Figure 2: The duration of convex knickpoint preservation as a function of slope exponent $n$ (a), $\gamma_{1 \_2}$ (b), and $\gamma_{0 \_1}$ (c). In (a),

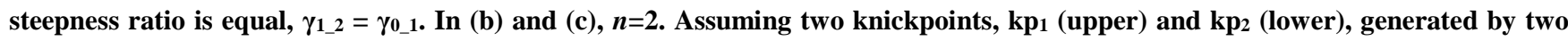
step increases in tectonic uplift rates, $T_{1}$ dates the time between the formation of $\mathrm{kp}_{1}$ and the formation of $\mathrm{kp}_{2}$, and $\mathrm{T}_{2} \mathrm{~m}$ dates the time from the emergence of $\mathrm{kp}_{2}$ to the its merging with $\mathrm{kp}_{1} \cdot \gamma_{1 \_} 2$ is the ratio of steepness indices above and below kp2, and $\gamma_{0} 1$ is the ratio of steepness indices above and below $\mathrm{kp}_{1}$.
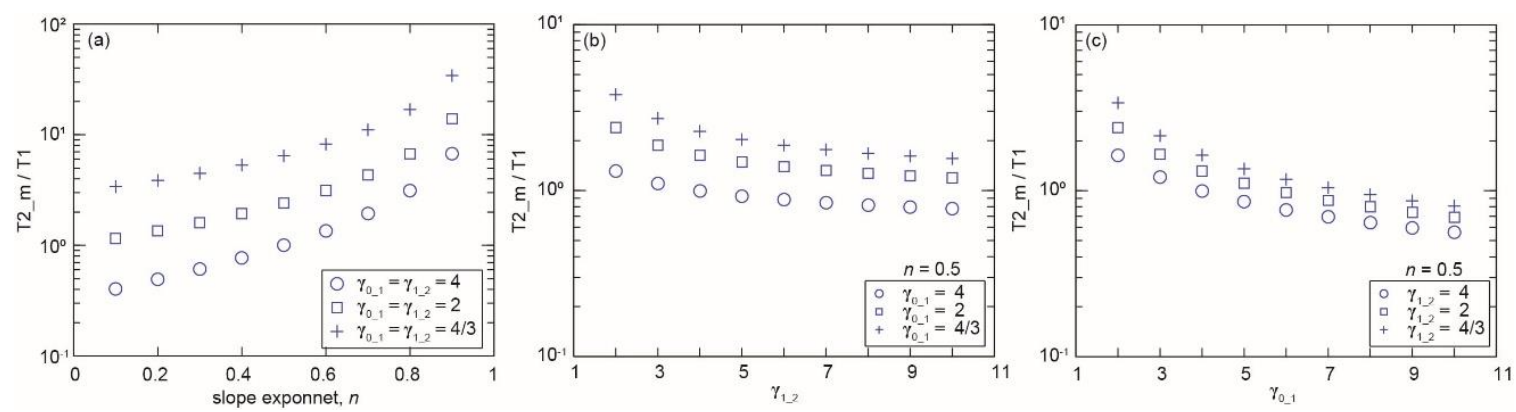

Figure 3: The duration of concave knickpoint preservation as function of the slope exponent $n$ (a), $\gamma_{1 \_2}$ (b), and $\gamma_{0 \_1}$ (c), under decreasing $U$ and $n<1$. In (a), steepness ratio is equal, $\gamma_{1 \_2}=\gamma_{0 \_1}$. In panels (b) and (c), $n=0.5$. 
https://doi.org/10.5194/esurf-2021-101

Preprint. Discussion started: 21 December 2021

(c) Author(s) 2021. CC BY 4.0 License.

(c) (i)
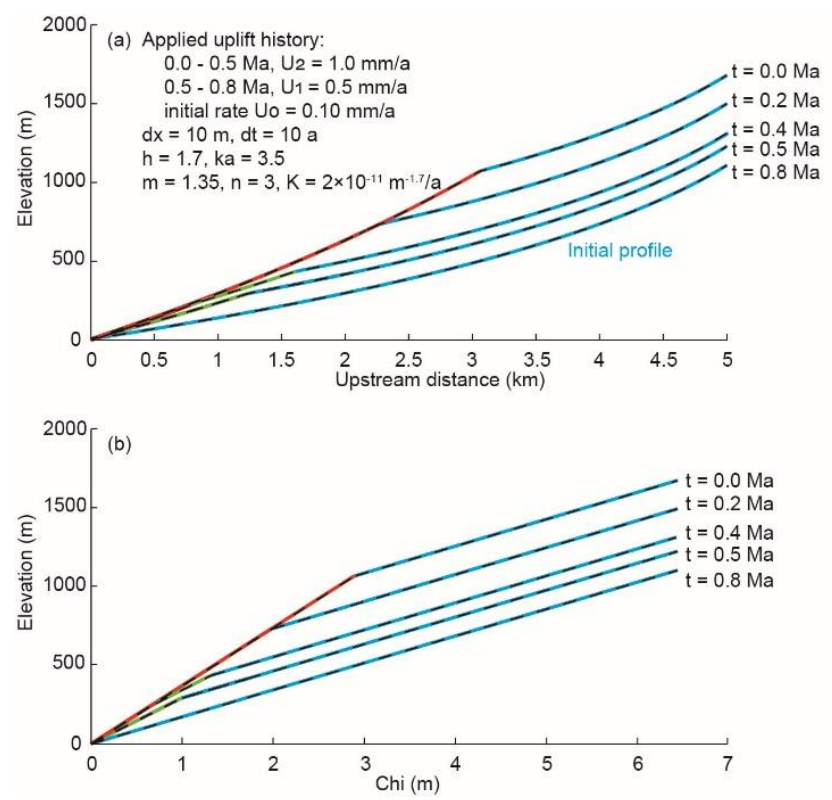

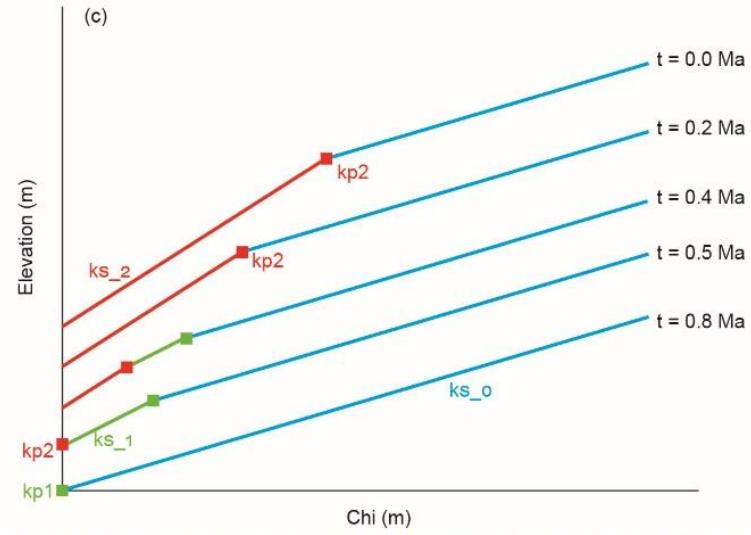

At $0.8 \mathrm{Ma}, \mathrm{kp} 1$ formed at the river outlet, due to an increase in the uplift rate from $\mathrm{U}_{0}$ to $\mathrm{U}_{1}$ At $0.5 \mathrm{Ma}, \mathrm{kp} 2$ formed at the river outlet, due to an increase in the uplift rate from $\mathrm{U}_{1}$ to $\mathrm{U}_{2}$ At $0.2 \mathrm{Ma}$, $\mathrm{kp} 1$ and $\mathrm{kp} 2$ merged ( $\mathrm{kp} 1$ was consumed by $\mathrm{kp} 2$ and only $\mathrm{kp} 2$ was preserved)

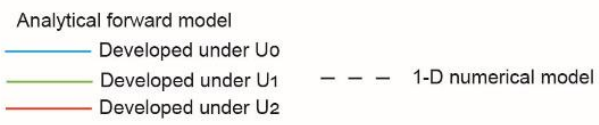

520 Figure 4: Evolution of a river long profile, with drainage area set by Hack's law, $A=k_{a}(L-x)^{h}$. Parameters $\left(n, K, m, k_{a}\right.$, and $\left.h\right)$ and the applied uplift history are described in panel a. $L$, total river length, is $6 \mathrm{~km}$ (colluvial-channel length is $1 \mathrm{~km})$. The analytic (colored, solid) and numerical solutions (black, dashed) match in the $x-z$ (a) and $\chi-z$ (b) domains. Panel (c) depicts the river $\chi-z$ long profiles offset in elevation, demonstrating knickpoint merging dynamics.
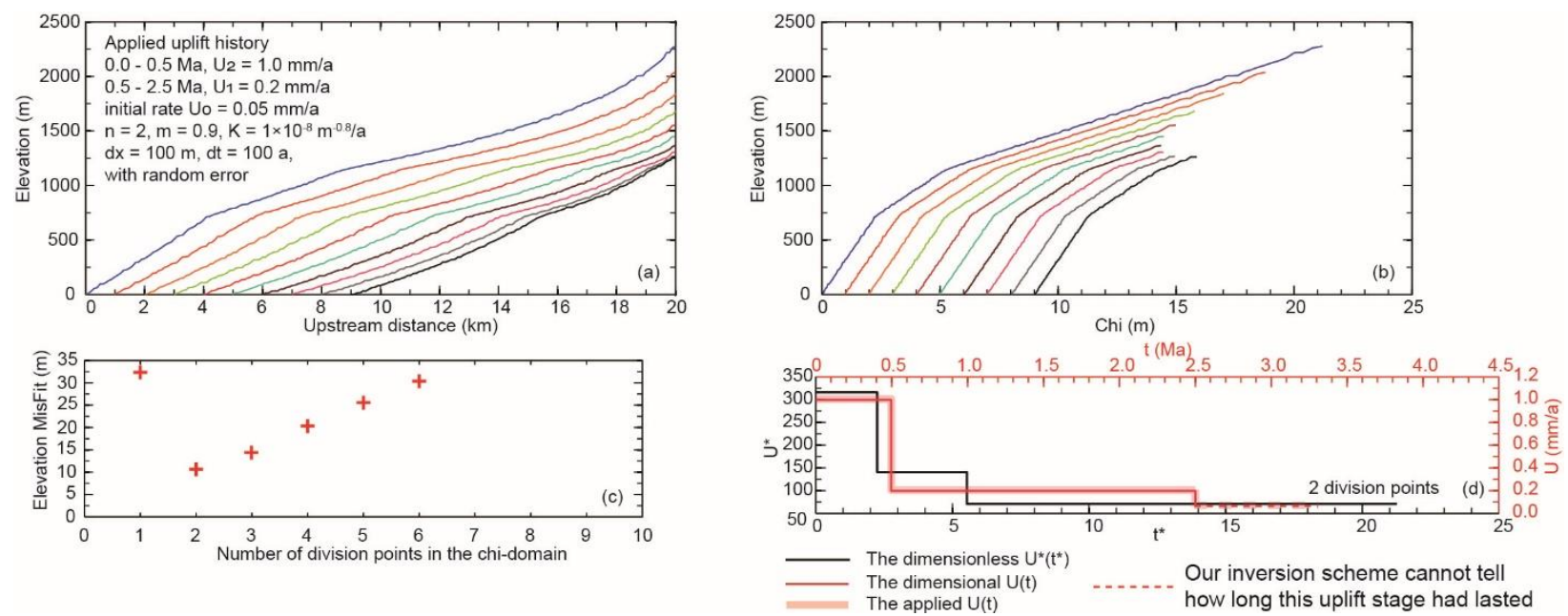

Figure 5: River profile inversion. (a-b) River profiles and $\chi-z$ plots generated via numerical model, with river length $\sim 12$ to $21 \mathrm{~km}$, $k_{a} \sim 2$ to 1.55, and $h \sim 0.67$ to 4.27. (c) Elevation misfit, equation 28, as a function of the number of division points. (d) The inverted uplift history, based on 2 division points. 